\title{
Article \\ Nutritional Value and Bioactive Compounds of Leaves and Grains from Quinoa (Chenopodium quinoa Willd.)
}

\author{
Elena Villacrés ${ }^{1, *(\mathbb{D}}$, María Quelal ${ }^{1}{ }^{\mathbb{C}}$, Susana Galarza ${ }^{2}$, Diana Iza ${ }^{3}$ and Edmundo Silva ${ }^{4}$ \\ 1 Departamento de Nutrición y Calidad, Instituto Nacional de Investigaciones Agropecuarias, \\ Mejía 171108, Ecuador; maria.quelal@iniap.gob.ec \\ 2 Facultad de Ciencias Agropecuarias y Recursos Naturales, Universidad Técnica de Cotopaxi, \\ Latacunga 050108, Ecuador; susi29m@hotmail.com \\ 3 Facultad de Ciencias Químicas, Universidad Central del Ecuador, Quito 170129, Ecuador; \\ diana.9122@outlook.com \\ 4 Facultad de Ingeniería Química, Universidad de Guayaquil, Guayaquil 090514, Ecuador; \\ edmundosilvapaguay@hotmail.es \\ * Correspondence: elena.villacres@iniap.gob.ec
}

Citation: Villacrés, E.; Quelal, M.; Galarza, S.; Iza, D.; Silva, E. Nutritional Value and Bioactive Compounds of Leaves and Grains from Quinoa (Chenopodium quinoa Willd.). Plants 2022, 11, 213. https:// doi.org/10.3390/plants11020213

Academic Editors: Anna Oniszczuk and Karolina Wojtunik-Kulesza

Received: 22 December 2021

Accepted: 10 January 2022

Published: 14 January 2022

Publisher's Note: MDPI stays neutral with regard to jurisdictional claims in published maps and institutional affiliations.

Copyright: (C) 2022 by the authors. Licensee MDPI, Basel, Switzerland. This article is an open access article distributed under the terms and conditions of the Creative Commons Attribution (CC BY) license (https:// creativecommons.org/licenses/by/ $4.0 /)$.

\begin{abstract}
Quinoa is an important crop for food security and food sovereignty in Ecuador. In this study, we evaluated the nutritional value, bioactive compounds, and antinutrient compounds of leaves and grains of the Ecuadorian quinoa variety Tunkahuan, and we identified significant differences between the nutrient content in the leaves and grains. The quinoa leaves presented a higher protein content than the grains, as well as inorganic nutrients such as calcium, phosphorus, iron, and zinc. Both the grains and leaves had an appreciable phenolic content. In addition, the quinoa grains presented a higher content of the antinutrient saponin than the leaves, while the leaves contained more nitrates and oxalates than the grains. Thus, quinoa leaves and grains exhibit excellent potential for application in the food and pharmaceutical industries.
\end{abstract}

Keywords: quinoa grains; leaves; nutritional value; bioactive compounds; antinutritional factors

\section{Introduction}

Quinoa is an important and environmental stress-tolerant pseudocereal with high nutritional value and a globally promoted cultivar for human consumption and nutrition [1] Quinoa plants, originating from the Andean mountains in South America, have a large scale of biological diversity [2]. However, after being abandoned in favor of old-world crops, it is now starting to be rediscovered by modern scientific approaches [1].

Quinoa is a complete food with high-nutritional value due mainly to its high content of good quality protein and are also called "the mother grain" [3]. The Ecuadorian varieties of quinoa contain more fat and protein than other Andean varieties. Quinoa's superiority over other grains (maize, wheat, and barley, among others) results from its richer protein, lipid, and ash content. Albumins and globolins represent the major storage quinoa proteins. In addition, quinoa proteins are accepted as high quality [4], and the lysine content is higher than that of rice and wheat [5]. According to the Food and Agriculture Organization (FAO), the quinoa grain is a vegetal food that provides all essential amino acids and fulfills the dietary requirement established for human nutrition [6]. The Tunkahuan quinoa variety was obtained by selection of a population of germplasm collected in the Province of Carchi (Ecuador) in 1985. Then, it was officially released as a variety in 1992. This variety is adapted in areas between $2200 \mathrm{~m}$ and $3200 \mathrm{~m}$, and its yield is from $1500 \mathrm{~kg} / \mathrm{ha}$ to $3000 \mathrm{~kg} / \mathrm{ha}$. Other important morphological descriptors of this variety are leaf size (large), leaf shape (triangular), days of panning (70-110), and days to harvest (150-210). Among the nutritional components, there are the protein $(15.73 \%)$, fat $(6.11 \%)$, and carbohydrate $(60.37 \%)$ content [7]. 
Moreover, the grain contains adequate levels of micronutrients, such as vitamins and minerals (calcium, phosphorus, potassium, copper, iron, and zinc). Some factors such as the differences in drying and storage conditions, harvest time and fertilization, soil structure, climate, and irrigation affect the macro and micronutrient contents [8]. Antinutritional factors such as saponins, phytic acid, tannins, and protease inhibitors have also been identified in quinoa and can have a negative effect on the performance and survival of monogastric animals when it is used as the primary dietary energy source. Although, the presence of saponins is not limited to seeds and can be found in other parts of the plant, whose function is to protect against the adverse conditions of the outside environment. Although saponins impart a bitter flavor, they have found application in the production of hormones and immunological adjuvants and as potent natural insecticides [1,9]. Significant amounts of other bioactive compounds such as phytosterols, squalene, and other phenolic compounds, including quercetin and kaempferol glycosides, benzoic acids, protocatechuic acid, and vanillic acid derivatives, are also present in quinoa seeds. The antioxidant activity has been associated with their high content of phenolic compounds [4,10].

Research on quinoa has primarily focused on the nutrient composition of seeds, protein quality, starch functionality, and incorporation into food products made with cereal flours [11]. There are a lot of studies of quinoa leaves. The leaves contain many important potential nutrition, content of proteins, carbohydrates, lipids and dietary fiber, minerals such as $\mathrm{Fe}, \mathrm{Zn}, \mathrm{Na}$, and $\mathrm{K}$, and vitamins (provitamin $\mathrm{A}$, vitamin $\mathrm{E}$ ). Consumption of nutrient-rich leafy green quinoa may prevent nutritional deficiency caused by Fe and $\mathrm{Zn}[12,13]$. The quinoa leaves have a flavor similar to spinach and can be used in salads or cooked as a green vegetable. Their nutritional composition is similar to spinach; though, the protein from quinoa leaves contains more isoleucine and valine and slightly less methionine, cystine, phenylalanine, and tyrosine [13].

Moreover, bioactive compounds present a better nutritional profile than grains. Some studies have evaluated the nutraceutical potential of quinoa leaves in the context of bioaccessibility and bioavailability of their phenolic compounds, with in vitro studies suggesting that they can help prevent cancer and other diseases related to oxidative stress $[14,15]$. The aim of this study was to characterize the nutritional composition and bioactive compounds in the leaves and grains of the Tunkahuan variety of quinoa (Chenopodium quinoa Willd.), produced in Ecuador.

\section{Results}

\subsection{Proximate Composition}

Table 1 indicates the proximate composition and dietary fiber content of the quinoa leaves and grains. Statistical analysis (Student's $t$-test) confirmed significant differences between the leaves and grains. The ash and protein contents of the leaves were higher than those of the grains. In addition, the lipid content (ether extract) in grains was higher than in quinoa leaves, maize, and wheat. The crude protein content in leaves was higher than quinoa grains. The crude fiber content in leaves and grains was higher than that in maize, wheat, and spinach leaves. The quinoa leaves contained more dietary fiber (soluble and insoluble) than the grains. 
Table 1. Comparison of proximate composition and dietary fiber content of quinoa leaves with quinoa grains and other plant species ( $\mathrm{g} / 100 \mathrm{~g}$ dry weight of the sample).

\begin{tabular}{|c|c|c|c|c|c|}
\hline Parameters & Leaves & Quinoa Grains & Maize $^{a}$ & Wheat $^{\text {a }}$ & Spinach Leaves ${ }^{b}$ \\
\hline Moisture & $5.23 \pm 0.17$ & $12.00 \pm 0.11^{* *}$ & & & \\
\hline Ash & $19.86 \pm 0.16$ & $1.96 \pm 0.15^{* *}$ & $1.7^{* *}$ & $2.2 * *$ & $13.45 *$ \\
\hline Ether extract & $3.50 \pm 0.21$ & $6.00 \pm 0.22 * *$ & $4.70 *$ & $2.3^{*}$ & $4.65^{*}$ \\
\hline Protein & $27.84 \pm 0.36$ & $16.70 \pm 0.30 * *$ & $10.2^{* *}$ & $14.3^{* *}$ & $25.67 *$ \\
\hline Crude fiber & $8.02 \pm 0.24$ & $8.61 \pm 0.21 *$ & $2.3^{* *}$ & $2.8^{* *}$ & $7.33 *$ \\
\hline Nitrogen free extract & $40.78 \pm 0.40$ & $66.73 \pm 0.45^{* *}$ & $81.1^{* *}$ & $78.4^{* *}$ & $48.90 *$ \\
\hline Soluble dietary fiber (SDF) & $3.29 \pm 1.17$ & $0.74 \pm 0.28^{* *}$ & & & \\
\hline Insoluble dietary fiber (IDF) & $33.07 \pm 1.17$ & $10.36 \pm 0.14 * *$ & & & \\
\hline Total dietary fiber & $36.37 \pm 2.34$ & $11.10 \pm 0.15^{* *}$ & & & \\
\hline
\end{tabular}

Mean \pm standard deviation $(\mathrm{n}=3) ;{ }^{* *}$ highly significant; ${ }^{*}$ significant; ${ }^{a}$ Data according Koziol [16]; ${ }^{\mathrm{b}}$ Data according Hanif et al. [17].

\subsection{Amino Acid Analysis}

The amino acid profiles of quinoa grains and leaves are presented in Table 2. Statistical analysis (Student's $t$-test) confirmed the significant differences between leaves and grains and other plants. Essential amino acids (EAAs) such as phenylalanine, lysine, isoleucine, and threonine were found in higher proportions in the quinoa leaves than in the grains. In addition, the leaves presented higher lysine and isoleucine levels than grains of maize and wheat [18]. Other non-essential amino acids (NEAAs), such as glutamic acid, aspartic acid, and alanine, were present in significantly higher amounts in leaves than in quinoa grains and maize, wheat, and spinach leaves. Thus, both the leaves and grains of quinoa exhibited a higher content of NEAAs than EAAs, with the EAA content approximately $35 \%$ more than that of NEAAs. In contrast, the EEA/NEAA ratios in wheat, maize, and spinach were higher than that in quinoa grains and leaves.

Table 2. Comparison of amino acid profiles of quinoa leaves with quinoa grains and other plants ( $\mathrm{g} / 100 \mathrm{~g}$ protein dry weight of the sample).

\begin{tabular}{|c|c|c|c|c|c|c|}
\hline Amino Acids & Leaves & Quinoa Grains & Maize $^{a}$ & Wheat $^{\text {a }}$ & $\begin{array}{l}\text { Spinach } \\
\text { Leaves }^{b}\end{array}$ & $\begin{array}{c}\text { School } \\
\text { Children }^{+}\end{array}$ \\
\hline \multicolumn{7}{|l|}{ EAAs: } \\
\hline Histidine & $1.90 \pm 0.17$ & $2.31 \pm 0.25 *$ & $2.6^{*}$ & 2.0 & $2.5 *$ & 1.9 \\
\hline Isoleucine & $4.13 \pm 0.13$ & $2.87 \pm 0.13 *$ & 4.0 & 4.2 & 4.8 & $2.8 *$ \\
\hline Lysine & $4.24 \pm 0.16$ & $3.81 \pm 0.29 *$ & $2.9 *$ & $2.6 *$ & $7.3^{* *}$ & 4.4 \\
\hline Threonine & $3.88 \pm 0.10$ & $2.62 \pm 0.17 *$ & 3.8 & $2.8 *$ & $5.3 *$ & $2.8 *$ \\
\hline Valine & $2.84 \pm 0.14$ & $3.81 \pm 0.20 *$ & $5.0 *$ & $4.4^{*}$ & $6.1 *$ & 2.5 \\
\hline \multicolumn{7}{|l|}{ NEAAS: } \\
\hline Tyrosine & $2.91 \pm 0.04$ & $2.19 \pm 0.10$ & $0.7 *$ & $0.2 * *$ & ND & $0.9 * *$ \\
\hline Phenylalanine + tyrosine & $5.42 \pm 0.36$ & $3.31 \pm 0.23 *$ & $8.6 * *$ & $8.2 * *$ & $11.1^{* *}$ & $2.2 *$ \\
\hline Glutamic Acid & $16.12 \pm 0.22$ & $13.44 \pm 0.40^{*}$ & $18.8^{*}$ & $29.5^{* *}$ & $11.7^{*}$ & \\
\hline Aspartic Acid & $10.69 \pm 0.28$ & $7.68 \pm 0.35^{*}$ & $6.9 *$ & $5.0 *$ & 9.9 & \\
\hline Alanine & $10.41 \pm 0.39$ & $2.87 \pm 0.35^{* *}$ & $7.3 *$ & $3.6^{* *}$ & $6.3 *$ & \\
\hline Glycine & $8.90 \pm 0.12$ & $11.00 \pm 0.40$ * & $4.0^{* *}$ & $4.0 * *$ & $5.2 * *$ & \\
\hline Arginine & $5.06 \pm 0.08$ & $6.50 \pm 0.16^{*}$ & $4.2^{*}$ & $4.5^{*}$ & $6.4^{*}$ & \\
\hline Proline & $4.49 \pm 0.39$ & $2.87 \pm 0.12 *$ & $9.1^{* *}$ & $10.2^{* *}$ & 4.8 & \\
\hline Serine & $4.05 \pm 0.06$ & $8.19 \pm 0.10 *$ & $5.1 *$ & 4.8 & 4.8 & \\
\hline \multicolumn{7}{|c|}{ Nutritional evaluation } \\
\hline EAA & 22.4 & $18.7^{*}$ & $26.90 *$ & $24.20 *$ & $37.10 * *$ & \\
\hline NEAA & 63.3 & $55.0 *$ & $56.10 *$ & $61.80 *$ & $49.10 * *$ & \\
\hline TAA & 85.7 & $73.8 *$ & $83.00 *$ & 86.00 & 86.20 & \\
\hline EAA/TAA (\%) & 26.2 & 25.4 & $32.41 *$ & 28.14 * & $43.04 * *$ & \\
\hline NEAA/TAA (\%) & 73.8 & 74.6 & $67.59 *$ & 71.86 & $56.96 * *$ & \\
\hline EEA/NEAA (\%) & 35.4 & 34.0 & $47.95^{* *}$ & 39.16 * & $75.56 * *$ & \\
\hline
\end{tabular}

Mean \pm standard deviation $(\mathrm{n}=3)$, EAA $=$ essential amino acid; NEAA $=$ non-essential amino acid; TAA $=$ total

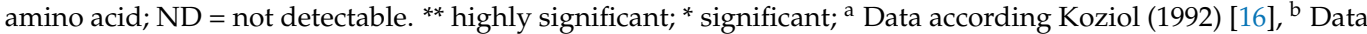
according Hanif et al. (2006) [17], ${ }^{+}$Data according Values from FAO (1985) [19]. 


\subsection{Mineral Content}

The macro and microminerals analyzed are listed in Table 3. There were statistically significant differences in mineral content between the quinoa leaves and grains. The ash content of the leaves was higher than that of quinoa grains, spinach leaves, and other grains. The leaves also contained calcium, magnesium, and potassium, and the microelements iron and zinc were in considerably higher quantities compared to other minerals. The calcium content in quinoa grains was higher than that in maize and wheat. However, the phosphorus content was higher in wheat than in quinoa grains. The quinoa leaves presented larger concentrations of valuable macroelements than spinach leaves, and higher iron and zinc levels than those of maize and wheat.

Table 3. Comparison of macro and microminerals in quinoa leaves with quinoa grains and other plants (dry weight of the sample).

\begin{tabular}{|c|c|c|c|c|c|}
\hline Minerals & Leaves & QuinoaGrain & Maize $^{a}$ & Wheat $^{a}$ & Spinach Leaves $^{b}$ \\
\hline \multicolumn{6}{|c|}{ Macroelements ${ }^{1}$} \\
\hline Calcium & $2.79 \pm 0.28$ & $0.18 \pm 0.03^{* *}$ & $0.02 * *$ & $0.05^{* *}$ & $0.08^{* *}$ \\
\hline Phosphorus & $0.63 \pm 0.25$ & $0.32 \pm 0.07 *$ & $0.29 *$ & $0.47 *$ & $0.08^{* *}$ \\
\hline Magnesium & $2.26 \pm 0.23$ & $0.16 \pm 0.08^{* *}$ & $0.14^{* *}$ & $0.17^{* *}$ & NR \\
\hline Potassium & $4.74 \pm 0.21$ & $0.33 \pm 0.12^{* *}$ & $0.34^{* *}$ & $0.58 * *$ & $0.20 * *$ \\
\hline Sodium & $0.05 \pm 0.01$ & $0.02 \pm 0.12 *$ & $0.01 *$ & $0.01 *$ & $0.06^{*}$ \\
\hline \multicolumn{6}{|c|}{ Microelements $^{2}$} \\
\hline Copper & $8.00 \pm 0.50$ & $0.60 \pm 0.10^{* *}$ & NR & $7 *$ & $0.000005^{* *}$ \\
\hline Iron & $483.00 \pm 1.00$ & $7.80 \pm 1.31^{* *}$ & $21^{* *}$ & $38^{* *}$ & $0.006^{* *}$ \\
\hline Manganese & $38.00 \pm 1.00$ & $1.00 \pm 0.50^{* *}$ & $5 *$ & 39 & NR \\
\hline Zinc & $204.00 \pm 2.00$ & $3.30 \pm 0.52 * *$ & $29 * *$ & $47^{* *}$ & NR \\
\hline
\end{tabular}

Mean \pm standard deviation $(\mathrm{n}=3) .{ }^{1}$ Expressed as $\mathrm{g} / 100 \mathrm{~g} .{ }^{2}$ expressed as $\mathrm{mg} / \mathrm{kg}$. NR: not reported; ${ }^{* *}$ highly significant; * significant; ${ }^{a}$ Data according Koziol (1992); ${ }^{b}$ Data according Hanif et al. (2006) [17].

\subsection{Antioxidant and Antinutritional Compounds}

The compounds with antioxidant properties analyzed in this study are shown in Table 4. Statistical analysis (Student's $t$-test) confirmed significant differences between leaves and grains in the content of antioxidant compounds, although the estimated antioxidant capacity was not significantly different. A high content of ascorbic acid was observed in the quinoa leaves, whereas it was not detected in the grains. Carotenoids, total phenols, flavonoids, and anthocyanins were also present in higher amounts in the quinoa leaves than in the grains. Among the antinutritional factors, saponin substances were present in higher concentrations in the grains than in the leaves, whereas nitrates and oxalates were more predominant in the leaves.

Table 4. Antioxidant and antinutrient compounds in quinoa leaves and grains (dry weight of the sample).

\begin{tabular}{ccc}
\hline Antioxidant Compounds & Leaves & Grain \\
\hline Ascorbic acid $(\mathrm{mg} / 100 \mathrm{~g})$ & $358.00 \pm 0.17$ & $\mathrm{ND}$ \\
Total carotenoids $(\mu \mathrm{g} \mathrm{RE} / \mathrm{g})$ & $1695.12 \pm 5.22$ & $13.89 \pm 1.01^{* *}$ \\
Total phenols $(\mathrm{mg}$ AGE/100 g) & $4902.53 \pm 6.4$ & $1110.39 \pm 1.63^{* *}$ \\
Flavonoids $(\mathrm{mg}$ quercetin/100 g) & $616.00 \pm 0.268$ & $9.48 \pm 1.12^{* *}$ \\
Anthocyanins $(\mathrm{mg} / 100 \mathrm{~g})$ & $49.36 \pm 0.56$ & $0.77 \pm 0.21^{* *}$ \\
Antioxidant capacity $(\mu \mathrm{Moles}$ & $44.16 \pm 0.72$ & $31.99 \pm 1.79$ \\
Trolox equivalent/g) & Antinutrient compounds & \\
Saponins $(\mathrm{mg} / 100 \mathrm{~g})$ & $0.49 \pm 0.01$ & $199.07 \pm 1.01^{* *}$ \\
Nitrates $(\mathrm{mg} / 100 \mathrm{~g})$ & $60.07 \pm 1.14$ & $21.83 \pm 1.61^{* *}$ \\
Oxalates $(\mathrm{mg} / 100 \mathrm{~g})$ & $12.85 \pm 0.25$ & $4.31 \pm 0.47^{* *}$ \\
\hline
\end{tabular}

Mean \pm standard deviation $(n=3)$. RE: retinol equivalents. AGE: gallic acid equivalent. ND: not detectable. ** highly significant. 


\section{Discussion}

The proximate composition of quinoa leaves and grains has been demonstrated to be richer than that of other cereals and leaves. In another study, the crude protein content of quinoa leaves was reported to be $14.77 \mathrm{~g} / 100 \mathrm{~g}$ (dry weight) [20]. Recent studies of crops of the same varieties (Bolivian and Argentinian) grown in different environments also reveal differences in total protein content, but without substantial losses and broadly maintaining the balance between the different amino acids [21,22]. In another study, with different quinoa varieties (Inia431-Altiplano, White, Titicaca, Illpa Inia, and Carmen) obtained from Adana Eastern Mediterranean Agricultural Research Institute, the protein content in the seed was within $12.96-16.84 \%$ [8]. The protein content of grains determined in this study was similar to values reported in other studies on different cultivars of quinoa [22-24]. The differences in protein content may be related to crop conditions; if the soil is rich in nitrogen, the plant produces more proteins than a plant cultivated in nitrogen-poor soil $[8,13,23]$. Nevertheless, the protein content of quinoa leaves $(27.84 \mathrm{~g} / 100 \mathrm{~g}$ as determined in this study) was higher than that from spinach $(25.67 \mathrm{~g} / 100 \mathrm{~g})$, amaranth, and moringa leaves. Leaf protein represents an important nutritional component and could play a key role in alleviating nutritional deficiency in rural populations $[13,17]$.

Grain oil is of high nutritional quality, containing several essential fatty acids; the predominant oleic and linoleic acids confer several positive health effects $[1,25]$. Both the leaves and grains analyzed in this study presented similar crude fiber content but were higher than that of lettuce $(0.7 \mathrm{~g} / 100 \mathrm{~g})$ and spinach $(0.6 \mathrm{~g} / 100 \mathrm{~g})$ [17]. Thus, quinoa leaves could be a good source of fiber that a normal body needs to function.

The major components of dietary fiber include cell wall polysaccharides (galacturonic acid, arabinose, galactose, xylose, and glucose). Dietary fiber is divided into soluble and insoluble fractions based on water solubility [26]. In this study, the soluble and insoluble dietary fiber contents of leaves were higher than those grains. Together, the total dietary fiber content of quinoa leaves and grains was similar to that of cereals such as wheat [4]. Repo-Carrasco and Serna [21] determined the contents of dietary fiber in quinoa samples to be $11.99-14.39 \%$ (IDF) and $1.41-1.60 \%$ (SDF). For yellow quinoa of 25 different cultivars, the ranges of insoluble and soluble fiber contents were 10-14, and 3.7-5.9\% respectively [27]; these results could be influenced by the quinoa variety, crop conditions, genetic conditions, and growing locations, which can all affect the fiber composition of quinoa [28,29]. The World Health Organization (WHO) recommends a dietary fiber intake of 20-35 g/per day for adults, in 3:1 proportion of IDF and SDF [26], which can be supplied by quinoa. Other studies have reported that the high fiber content of quinoa can improve digestibility by facilitating the absorption of other nutrients present in quinoa in the large intestine [9]. The quinoa fiber had more soluble fiber than cereals. The fiber composition was more similar to fruits than the cereals and had great potential to improve the functional and nutritional properties of food products [26].

Quinoa is one of the few plant foods that provides essential amino acids. Thus, quinoa proteins are accepted as high quality protein because of their balanced composition of essential amino acids, with the exception of tryptophan [4,5]. The quinoa grains contained higher amounts of valine and histidine than the leaves. Based on FAO/WHO/ United Nations (ONU)-recommended values, histidine, isoleucine, lysine, and valine amino acids can meet the requirements of school children and adults [16,19]. In addition, quinoa grains have higher lysine content than other cereals; some studies attributed the high lysine content to the existence of seven new proteins (globulins) similar to vicilin (legume reserve proteins) [30-32].

The macro and microminerals in quinoa leaves and grains were found at concentrations greater than those reported for maize, wheat, and spinach leaves. Several authors have reported that the mineral content of quinoa is adequate for a balanced diet [4]. Thus, the iron in quinoa shows good bioavailability [16], although antinutrients such as saponins and phytic acids can affect its bioavailability [33]. In addition, differences in mineral content have been observed in various studies on quinoa, which has been attributed to differences 
in plant genotypes, soil mineral composition or fertilizer application, uptake of minerals by individual plants, and organic soil amendments [9,13].

Bioactive compounds of quinoa were found mainly in the outer layers of the seeds, functioning as a chemical defense against insects and microorganisms [4,34]. Studies have demonstrated that antioxidant capacity in quinoa seeds is associated with the high content of phenolic compounds $[4,35]$. Quinoa leaves and seeds can provide important bioactive compounds with positive health effects. The total phenolic content of Tunkahuan leaves was significantly higher than that reported in other studies with other varieties of quinoa leaves [36,37]. In the seeds, the phenol content was similar to that of the red and white quinoa varieties derived from Bolivia and Chile [36]. For yellow quinoa of 25 different cultivars, the amount of phenolics in the cultivars were higher than reported in this study [27].

Some studies have established the chemical structure of phenolic compounds that confers potent antioxidant properties exerted through different mechanisms. They have the ability to scavenge free radicals and chelate metal ions, inhibit oxidases, terminate radical chain reactions, and stabilize free radicals [32].

In the case of flavonoids and anthocyanins, the leaves contained concentrations 98.47 times higher than those present in quinoa seeds. In another study, the flavonoid content of Chenopodium species varied from 36.2 to $144.3 \mathrm{mg} / 100 \mathrm{~g}$, and the predominant flavonoids were shown to be quercetin and kaempferol [38]. The rutin flavonoid content in leaves of two quinoa cultivars were reported to be $869 \mathrm{mg}$ and $914 \mathrm{mg} / 100 \mathrm{~g}$ [37]. The antioxidant capacity depends on the number and arrangement of hydroxyl groups in the food, which can decrease the progress of oxidation by transferring hydrogen atoms to radicals [39]. As shown in Table 4, the leaves had a slightly higher antioxidant capacity than the grains. The study has shown that the variation in polyphenol content among quinoa cultivars is linked to soil, climatic conditions, agronomical practices, genetic interactions (variety and cultivar), and stress conditions [40]. Thus, other non-phenolic compounds, such as ascorbic acid and carotenoids, may be the most likely contributors to the antioxidant activity in quinoa [9]. Finally, most reports on the nutraceutical potential of quinoa focus only on seeds, whereas only little information is available on the antioxidant potential of quinoa leaves [36]. Our results indicate that the leaves could offer important health benefits.

With respect to antinutritional compounds, other researchers have reported saponin content of $1260 \mathrm{mg} / 100 \mathrm{~g}$ and $970 \mathrm{mg} / 100 \mathrm{~g}$ in quinoa seeds and leaves, respectively [41]. The saponin content of quinoa varieties grown in Washington State, USA ranged from $381 \mathrm{mg} / 100 \mathrm{~g}$ to $2710 \mathrm{mg} / 100 \mathrm{~g}$ [42]. Washing the grains under running water and scrubbing can reduce the saponin content, although it also appears to affect the mineral content; the different analytical methods and the different levels of irrigation and water salinity could also affect the saponins content within the same cultivar. Some studies suggested that the saponins content increases with higher levels of water salinity and decreases with lower irrigation levels [41,43]. In contrast to saponin, nitrates and oxalates are present at higher concentrations in leaves than in seeds. Nitrates are concentrated in vacuole leaves and transport organs but are less abundant in flowers, tubers, and seeds [44]. The nitrate concentration in quinoa leaves is lower than that in amaranth and sangorache leaves (122.83 mg/100 g and $260 \mathrm{mg} / 100 \mathrm{~g}$, respectively), and in the seeds, it reaches concentrations of $20.01 \mathrm{mg} / 100 \mathrm{~g}$ (amaranth) and $34.61 \mathrm{mg} / 100 \mathrm{~g}$ (sangorache) [45]. Nitrogen fertilization and light intensity have been shown to be a major influence on the nitrate content of vegetables [44].

The concentration of oxalates in the leaves was $66.46 \%$ higher than that in the quinoa grain. In another study, the oxalate concentration in amaranth and quinoa grains were $184 \mathrm{mg} / 100 \mathrm{~g}$ to $232 \mathrm{mg} / 100 \mathrm{~g}$ dry weight, respectively [46]. However, a high dietary oxalate intake can influence mineral and trace element absorption in humans and may lead to calcium oxalate stone formation due to the ability of oxalate to form insoluble complexes with divalent cations in the gastrointestinal tract [46]. Thermal processes (boiling, 
blanching) and soaking can contribute to reducing the content of antinutrient compounds, as these compounds are highly water-soluble $[45,46]$.

\section{Materials and Methods}

\subsection{Plant Material}

Iniap Tunkahuan (Ecuador) quinoa leaves and grains were selected for this study. The plants were provided by the National Legumes Program and INIAP Andean Grains (Ecuador). They were grown in the Santa Catalina Experimental Station with the geographic location of altitude 3050 m.a.s.l, latitude UTM 9959382 m S, longitude 17 M0772618 m W. Ecuador does not have a defined season, but the quinoa was grown with an average rainfall of $600 \mathrm{~mm}$, temperature variation $\left(7-17^{\circ} \mathrm{C}\right)$, and sandy loam soil ( $\left.\mathrm{pH} 6.5\right)$. In the case of the soil, the fertilization application was $80 \mathrm{~kg}$ of nitrogen and $40 \mathrm{~kg}$ of $\mathrm{P}_{2} \mathrm{O}_{5}$ per hectare were applied for fertilization.

The quinoa leaves were harvested manually after cultivation for 80 days. The grains were harvested with a reaper for 170 days, threshed and classified in a Crippen Mfg. Inc (St. Louis, MO, USA) using sieves with pore sizes of $2.5 \mathrm{~mm}, 2.2 \mathrm{~mm}$, and $2 \mathrm{~mm}$. For this study, grains with an average diameter of $2.5 \mathrm{~mm}$ were used.

The samples were taken to the laboratory, classified, placed in polypropylene bags, frozen at $-20^{\circ} \mathrm{C}$ for $24 \mathrm{~h}$, and then freeze-dried using LABCONCO equipment (Kansas, MO, USA). The seeds were cleaned of dust and other contaminants. The leaves and grains were milled (Retsch KG 5657 Haan, Remscheid, Germany) to a particle size of $250 \mu \mathrm{m}$, and the ground powder was packed in polypropylene bags and stored in a cool, dry place $\left(4^{\circ} \mathrm{C}\right)$ until further analysis.

\subsection{Proximate Compositon}

The protein, fat, crude fiber, and ash contents were determined according to the Association of Official Analytical Chemistry (AOAC) standardized methods [47]. Carbohydrate content was calculated using the difference in dry weight.

\subsection{Soluble and Insoluble Dietary Fiber}

SDF and IDF were quantified by sequential enzymatic digestion of quinoa leaves and grains by heat-stable $\alpha$-amylase, protease, and amyloglucosidase. The IDF was filtered, and the residue was washed with distilled water, ethanol, and acetone. The combined solution of filtrate and water washings were precipitated with ethanol for SDF determination. The precipitate was filtered and dried, and both residues (IDF and SDF) were corrected for protein, ash, and blank for calculation of fiber content (AOAC 991.43) [48].

\subsection{Amino Acid Analysis}

The amino acid profile was determined using high-performance liquid chromatography. The processed leaf and grain samples were applied to an LC-10AS Shimadzu liquid chromatography system, which operated under the following conditions: oven temperature, $60^{\circ} \mathrm{C}$; excitation wavelength, $350 \mathrm{~nm}$; emission wavelength, $450 \mathrm{~nm}$; sample cooler temperature, $4{ }^{\circ} \mathrm{C}$; eluent solution flow, $0.60 \mathrm{~m}^{2} \mathrm{~min}^{-1}$; injection volume, $5 \mu \mathrm{L}$; run time, $45 \min [47]$.

\subsection{Mineral Composition}

The mineral content in quinoa leaves and grains was determined using wet oxidation and atomic absorption spectrophotometry on an AA-7000 spectrophotometer (Shimadzu, Kyoto, Japan), except for phosphorus, which was analyzed by colorimetry [47]. 


\subsection{Antioxidant Compounds}

\subsubsection{Total Carotenoids}

Total carotenoid content was determined using cold acetone and petroleum ether. Absorbance was measured at $450 \mathrm{~nm}$. The carotenoid content was calculated using an extinction coefficient of 2500 [49].

\subsubsection{Ascorbic Acid}

Ascorbic acid was determined by reflectometric analysis using a test strip that monitors the reduction of yellow molybdophosphoric acid to phosphomolybdenum blue by ascorbic acid. The processed quinoa samples were diluted in distilled water and stirred thoroughly. The test strip was then dipped in the solution, excess liquid was allowed to run off via the long edge of the strip on to absorbent paper, and then the strip was analyzed using a reflectometer. The results were expressed in $\mathrm{mg} / 100 \mathrm{~g}$ dry weight [50].

\subsubsection{Polyphenolic Compounds}

Polyphenolic compounds were quantified using Folin Ciocalteau $2 \mathrm{~N}$ reagent; the absorbance was measured at $765 \mathrm{~nm}$, and the results were expressed in $\mathrm{mg}$ gallic acid/100 $\mathrm{g}$ dry sample [51]. Total anthocyanins were extracted with ethanol solution and $\mathrm{HCl}$ and were quantified by measuring absorbance at $515 \mathrm{~nm}$ on an Evolution 201 spectrophotometer (Thermo Fisher Scientific, Waltham, MA, USA). The total anthocyanin content was calculated using an extinction coefficient of 27300 [52].

\subsubsection{Antioxidant Capacity}

Trolox equivalent antioxidant capacity (TEAC) was determined by measuring reduction of 2,2'-azino-bis (3-ethylbenzothiazoline-6-sulfonic acid) in 80\% methanol and comparing against a Trolox standard curve. TEAC was expressed as $\mu$ mol Trolox equivalent/g dry weight [53].

\subsection{Antinutritional Compounds \\ 4.7.1. Nitrates}

Nitrate content was determined using a test strip that measures the reduction of nitrate ions by a reducing agent. The processed quinoa leaf samples were added to distilled water and were homogenized and centrifuged for $10 \mathrm{~min}$ at $10,000 \times \mathrm{g}$. Then, sulfuric acid $(72 \%)$ and distilled water were added to a portion of the extract and were incubated for $2 \mathrm{~h}$ at $100{ }^{\circ} \mathrm{C}$. The strip with the sample was analyzed using a reflectometer. The results were expressed as $\mathrm{mg} / 100 \mathrm{~g}$ (dry weight basis) [54].

\subsubsection{Saponin Content}

Saponin content was determined by spectrophotometry. Samples were first homogenized with ethanol (25\%); the extract was filtered, and then an aliquot of the extract was mixed with a color reagent (sulfuric acid:acetic anhydrous 3:1 v/v). Absorbance was measured at $528 \mathrm{~nm}$ and compared against a pure saponin standard. The saponin content was expressed as $\mathrm{mg} / 100 \mathrm{~g}$ dry weight [55].

\subsubsection{Oxalic Acid}

Oxalic acid concentration was determined by titration with $0.001 \mathrm{~N} \mathrm{KMNO}_{4}$ according to a previously reported method, with some modifications. The samples were placed in a muffle furnace for $10 \mathrm{~h}$ at $350{ }^{\circ} \mathrm{C} . \mathrm{H}_{2} \mathrm{SO}_{4}$ and distilled water $(25 \mathrm{~mL})$ were then added to the ash. The solution was filtered, warmed to approximately $60{ }^{\circ} \mathrm{C}$, and used for titration. An oxalic acid equivalent (45 Eq/g) was used for the calculation [56].

\subsection{Statistical Analysis}

The samples were analyzed in triplicate, and the results are expressed as mean and standard deviation (SD). Student's $t$-test was used to identify significant differences be- 
tween leaves and grains. The INFOSTAT software package was used for the statistical analysis [57].

\section{Conclusions}

Quinoa is a pseudocereal with high nutritional value. The leaves and grains of quinoa could be considered functional foods as they contain adequate protein, dietary fiber, minerals, and important bioactive compounds. However, quinoa can also present antinutrient compounds, whose content can vary depending on the plant organ, and can be reduced using thermal processing. Moreover, the leaves have a higher mineral content and may help to overcome nutritional deficiencies. Antioxidant compounds such as ascorbic acid, carotenoids, and phenolic compounds are also highlighted. The leaves have antinutritional compounds; however, the levels found in the leaves are low and within what is allowed for human consumption. The results of the research show that the leaves can be used in culinary preparations, in the elaboration of functional foods, and in the extraction of bioactive compounds for the food or pharmaceutical industry.

Author Contributions: Conceptualization: E.V. and M.Q.; methodology: S.G., D.I., and E.S.; software: M.Q.; validation: E.V.; formal analysis: S.G., D.I., and E.S.; resources: E.V.; writing-original draft preparation: M.Q.; writing-review and editing: E.V. and M.Q. All authors have read and agreed to the published version of the manuscript.

Funding: This research received no external funding.

Institutional Review Board Statement: Not applicable.

Informed Consent Statement: Not applicable.

Data Availability Statement: The data presented in this study are available on request from the corresponding author.

Conflicts of Interest: The authors declare no conflict of interest.

\section{References}

1. Vega-Gálvez, A.; Miranda, M.; Vergara, J.; Uribe, E.; Puente, L.; Martínez, E.A. Nutrition facts and functional potential of quinoa (Chenopodium quinoa willd.), an ancient Andean grain: A review. J. Sci. Food Agric. 2010, 90, 2541-2547. [CrossRef] [PubMed]

2. Abd El-Hakim, A.F.; Mady, E.; Abou Tahoun, A.M.; Ghaly, M.S.A.; Eissa, M.A. Seed Quality and Protein Classification of Some Quinoa Varieties. J. Ecol. Eng. 2022, 23, 24-33. [CrossRef]

3. Nisar, M.; More, D.R.; Zubair, S.; Hashmi, S.I. Physico-chemical and nutritional properties of quinoa seed: A review. J. Pharmacogn. Phytochem. 2017, 6, 2067-2069.

4. Vilcacundo, R.; Hernández-Ledesma, B. Nutritional and biological value of quinoa (Chenopodium quinoa Willd.). Food Microbiol. Funct. Foods Nutr. 2017, 14, 1-6. [CrossRef]

5. Quelal, M.; Nazate, K.; Villacrés, E.; Cuarán, J. Obtención y caracterización de un hidrolizado proteico de quinua Chenopodium quinoa Willd. Enfoque UTE 2019, 10, 79-89. [CrossRef]

6. Martínez, A. Estado del arte de la quinua en el mundo en 2013. In Quinua: Aspectos Nutricionales del Arroz de los Incas; Bazile, D., Bertero, D., Nieto, C., Eds.; FAO: Santiago, Chile; y CIRAD: Montpellier, Francia, 2013; pp. 331-340.

7. Peralta, E. La quinua en Ecuador; Estación Experimental Santa Catalina-INIAP: Quito, Ecuador, 2009.

8. Ayaşan, T. Determination of nutritional value of some quinoa varieties. Turk. J. Vet. Anim. Sci. 2020, 44, 950-954. [CrossRef]

9. Filho, A.M.M.; Pirozi, M.R.; Borges, J.T.D.S.; Pinheiro Sant'Ana, H.M.; Chaves, J.B.P.; Coimbra, J.S.D.R. Quinoa: Nutritional, functional, and antinutritional aspects. Crit. Rev. Food Sci. Nutr. 2017, 57, 1618-1630. [CrossRef]

10. Alvarez-Jubete, L.; Wijngaard, H.; Arendt, E.K.; Gallagher, E. Polyphenol composition and in vitro antioxidant activity of amaranth, quinoa buckwheat and wheat as affected by sprouting and baking. Food Chem. 2010, 119, 770-778. [CrossRef]

11. Lamothe, L.M.; Srichuwong, S.; Reuhs, B.L.; Hamaker, B.R. Quinoa (Chenopodium quinoa W.) and amaranth (Amaranthus caudatus L.) provide dietary fibres high in pectic substances and xyloglucans. Food Chem. 2015, 167, 490-496. [CrossRef]

12. Stoleru, V.; Jacobsen, S.-E.; Vitanescu, M.; Jitareanu, G.; Butnariu, M.; Munteanu, N.; Stan, T.; Teliban, G.C.; Cojocaru, A.; Mihalache, G. Nutritional and antinutritional compounds in leaves of quinoa. Food Biosci. 2022, 45, 101494. [CrossRef]

13. Pathan, S.; Eivazi, F.; Valliyodan, B.; Paul, K.; Ndunguru, G.; Clark, K. Nutritional composition of the green leaves of quinoa (Chenopodium quinoa Willd.). J. Food Res. 2019, 8, 55-65. [CrossRef]

14. Gawlik-Dziki, U.; Świeca, M.; Sułkowski, M.; Dziki, D.; Baraniak, B.; Czyż, J. Antioxidant and anticancer activities of Chenopodium quinoa leaves extracts-In vitro study. Food Chem. Toxicol. 2013, 57, 154-160. [CrossRef] [PubMed] 
15. Lin, M.; Han, P.; Li, Y.; Wang, W.; Lai, D.; Zhou, L. Quinoa secondary metabolites and their biological activities or functions. Molecules 2019, 24, 2512. [CrossRef] [PubMed]

16. Kozioł, M.J. Chemical composition and nutritional evaluation of quinoa (Chenopodium quinoa Willd.). J. Food Compos. Anal. 1992, 5, 35-68. [CrossRef]

17. Hanif, R.; Iqbal, Z.; Iqbal, M.; Hanif, S.; Rasheed, M. Use of vegetables as nutritional food: Role in human health. J. Agric. Biol. Sci. 2006, 1, 18-22

18. Valcárcel-Yamani, B.; Lannes, S.C.D.S. Applications of quinoa (Chenopodium quinoa Willd.) and amaranth (Amaranthus spp.) and their influence in the nutritional value of cereal based foods. Food Public Health 2012, 2, 265-275.

19. FAO. Energy and Protein Requirements: Report of a Joint FAO/WHO/UNU Expert Consultation; World Health Organization: Geneva, Switzerland, 1985; ISBN 92-4-120724-8.

20. Vázquez-Luna, A.; Pimentel, V.C.; Carmona, F.F.; Sobac, R.D. Quinoa leaf as a nutritional alternative. J. Agric. Nat. Resour. 2019, 46, 137-143. [CrossRef]

21. Gonzalez, J.A.; Konishi, Y.; Bruno, M.; Valoy, M.; Prado, F.E. Interrelationships among seed yield, total protein and amino acid composition of ten quinoa (Chenopodium quinoa) cultivars from two different agroecological regions. J. Sci. Food Agric. 2012, 92, 1222-1229. [CrossRef]

22. Miranda, M.; Vega-Gálvez, A.; Quispe-Fuentes, I.; Rodríguez, M.J.; Maureira, H.; Martínez, E.A. Nutritional aspects of six quinoa (Chenopodium quinoa Willd.) ecotypes from three geographical areas of Chile. Chil. J. Agric. Res. 2012, 72, 175-181. [CrossRef]

23. Repo-Carrasco-Valencia, R. Nutritional Value and Bioactive Compounds in Andean Ancient Grains. Proceedings 2020, 53, 1. [CrossRef]

24. Repo-Carrasco-Valencia, R. Andean Indigenous Food Crops: Nutritional Value and Bioactive Compounds; Department of Biochemistry and Food Chemistry, University of Turku: Turku, Finlandia, 2011.

25. Villacrés, E.; Pástor, G.; Quelal, M.B.; Zambrano, I. Effect of processing on the content of fatty acids, tocopherols and sterols in the oils of quinoa (Chenopodium quinoa Willd), lupine (Lupinus mutabilis Sweet), amaranth (Amaranthus caudatus L.) and sangorache (Amaranthus quitensis L.). Glob. Adv. Res. J. Food Sci. Technol. 2013, 2, 44-53.

26. Zhu, F. Dietary fiber polysaccharides of amaranth, buckwheat and quinoa grains: A review of chemical structure, biological functions and food uses. Carbohydr. Polym. 2020, 248, 116819. [CrossRef] [PubMed]

27. Sobota, A.; Świeca, M.; Gesiński, K.; Wirkijowska, A.; Bochnak, J. Yellow-coated quinoa (Chenopodium quinoa Willd)—physicochemical, nutritional, and antioxidant properties. J. Sci. Food Agric. 2020, 100, 2035-2042. [CrossRef] [PubMed]

28. Repo-Carrasco-Valencia, R.A.-M.; Serna, L.A. Quinoa (Chenopodium quinoa, Willd.) as a source of dietary fiber and other functional components. Food Sci. Technol. 2011, 31, 225-230. [CrossRef]

29. Liu, J.; Wang, Z.; Wang, Z.; Hao, Y.; Wang, Y.; Yang, Z.; Li, W.; Wang, J. Physicochemical and Functional Properties of Soluble Dietary Fiber from Different Colored Quinoa Varieties (Chenopodium Quinoa Willd). J. Cereal Sci. 2020, 95, 103045. [CrossRef]

30. Craine, E.B.; Murphy, K.M. Seed Composition and Amino Acid Profiles for Quinoa Grown in Washington State. Front. Nutr. 2020, 7, 126. [CrossRef] [PubMed]

31. Rojas, W.; Vargas Mena, A.; Pinto Porcel, M. La diversidad gen $\tilde{A} \backslash$ copyrighttica de la quinua: Potenciales usos en el mejoramiento y agroindustria. Rev. Investig. e Innovaci $\backslash$ textthreesuperiorn Agropecu. y Recur. Nat. 2016, 3, 114-124.

32. Hernández-Ledesma, B. Quinoa (Chenopodium quinoa Willd.) as source of bioactive compounds: A review. Bioact. Compd. Health Dis. 2019, 2, 27-47. [CrossRef]

33. Navruz-Varli, S.; Sanlier, N. Nutritional and health benefits of quinoa (Chenopodium quinoa Willd.). J. Cereal Sci. 2016, 69, 371-376. [CrossRef]

34. Tang, Y.; Tsao, R. Phytochemicals in quinoa and amaranth grains and their antioxidant, anti-inflammatory, and potential health beneficial effects: A review. Mol. Nutr. Food Res. 2017, 61, 1600767. [CrossRef]

35. Carciochi, R.A.; Manrique, G.D.; Dimitrov, K. Changes in phenolic composition and antioxidant activity during germination of quinoa seeds (Chenopodium quinoa Willd.). Int. Food Res. J. 2014, 21, 767-773.

36. Zlotek, U.; Gawlik-Dziki, U.; Dziki, D.; Świeca, M.; Nowak, R.; Martinez, E. Influence of Drying Temperature on Phenolic Acids Composition and Antioxidant Activity of Sprouts and Leaves of White and Red Quinoa. J. Chem. 2019, 2019, 7125169. [CrossRef]

37. Chacaliaza, L.; Espinoza, G.; Ramos, F.; Servan, K. Proximate chemical composition and content of biologically active components in leaves of two quinoa cultivars (Salcedo and Altiplano) produced in Peru. Res. J. Med. Plant 2016, 10, 450-456.

38. Repo-Carrasco-Valencia, R.; Hellström, J.K.; Pihlava, J.-M.; Mattila, P.H. Flavonoids and other phenolic compounds in Andean indigenous grains: Quinoa (Chenopodium quinoa), kañiwa (Chenopodium pallidicaule) and kiwicha (Amaranthus caudatus). Food Chem. 2010, 120, 128-133. [CrossRef]

39. Londoño, J. Antioxidantes: Importancia biológica y métodos para medir su actividad. In Desarrollo y Transversalidad; Universidad LaSallista: Antoquia, Colombia, 2012.

40. García-Parra, M.; Roa-Acosta, D.; García-Londoño, V.; Moreno-Medina, B.; Bravo-Gomez, J. Structural Characterization and Antioxidant Capacity of Quinoa Cultivars Using Techniques of FT-MIR and UHPLC/ESI-Orbitrap MS Spectroscopy. Plants 2021, 10, 2159. [CrossRef]

41. Lim, J.G.; Park, H.-M.; Yoon, K.S. Analysis of saponin composition and comparison of the antioxidant activity of various parts of the quinoa plant (Chenopodium quinoa Willd.). Food Sci. Nutr. 2020, 8, 694-702. [CrossRef] 
42. Medina-Meza, I.G.; Aluwi, N.A.; Saunders, S.R.; Ganjyal, G.M. GC-MS Profiling of Triterpenoid Saponins from 28 Quinoa Varieties (Chenopodium quinoa Willd.) Grown in Washington State. J. Agric. Food Chem. 2016, 64, 8583-8591. [CrossRef]

43. Nowak, V.; Du, J.; Charrondière, U.R. Assessment of the nutritional composition of quinoa (Chenopodium quinoa Willd.). Food Chem. 2016, 193, 47-54. [CrossRef]

44. Ranasinghe, R.; Marapana, R. Nitrate and nitrite content of vegetables: A review. Ournal Pharmacogn. Phytochem. 2018, 7, 322-328.

45. Gómez Ponce, A.D. Selección de un Proceso de Transformación para la Disminución de Compuestos Antinutricionales en el Grano y hojas de Amaranto (Amaranthus caudatus L.) y Sangorache (Amaranthus hybridus L.); Escuela Politécnica Nacional: Quito, Ecuador, 2013.

46. Siener, R.; Hönow, R.; Seidler, A.; Voss, S.; Hesse, A. Oxalate contents of species of the Polygonaceae, Amaranthaceae and Chenopodiaceae families. Food Chem. 2006, 98, 220-224. [CrossRef]

47. AOAC. AOAC Official Methods of Analysis, 17th ed.; AOAC International.: Arlington, VA, USA, 2000.

48. AOAC. AOAC Official Methods of Analysis, 16th ed.; AOAC International.: Arlington, VA, USA, 1995.

49. Rodriguez-Amaya, D.; Kimura, M. Harvest Plus Handbook for Carotenoid Analysis. Harvest Plus Technical Monograph 2; International Food Policy Research Institute (IFPRI) and International Center for TYropical Agriculture (CIAT): Washington, DC, USA, 2004.

50. Merck. Reflectoquant. Test de Ácido ascórbico (Vol.1.16981.0001); Merck: Darmstadt, Germany, 2016.

51. Waterhouse, A.L. Determination of total phenolics. Curr. Protoc. Food Anal. Chem. 2002, 6, I1.1.1-I1.1.8.

52. Jansen, G.; Flamme, W. Coloured potatoes (Solanum Tuberosum L.)—Anthocyanin Content and Tuber Quality. Genet. Resour. Crop Evol. 2006, 53, 1321. [CrossRef]

53. Re, R.; Pellegrini, N.; Proteggente, A.; Pannala, A.; Yang, M.; Rice-Evans, C. Antioxidant activity applying an improved ABTS radical cation decolorization assay. Free Radic. Biol. Med. 1999, 26, 1231-1237. [CrossRef]

54. Merck. Reflectoquant. Nitrate Test (Vol:1.16971.0001-1.6995.0001); Merck: Darmstadt, Germany, 2021.

55. Guzmán, B.; Cruz, D.; Alvarado, J.A.; Mollinedo, P. Cuantificación de saponinas en muestras de cañihua (Chenopodium pallidicaule A). Rev. Boliv. Química 2009, 30, 131-136.

56. Abaza, R.H.; Blake, J.T.; Fisher, E.J. Oxalate Determination: Analytical Problems Encountered with Certain Plant Species. J. Assoc. Off. Anal. Chem. 1968, 51, 963-967. [CrossRef]

57. Di Rienzo, J.; Casanoves, F.; Balzarini, M.G.; González, L.; Julio, A.; Tablada, M.; Robledo, C.W. InfoStat; Grupo InfoStat; FCA, Universidad Nacional de Córdoba: Córdoba, Argentina, 2015. 